\title{
Fast Determination of Naproxen in Pharmaceutical Formulations by Batch Injection Analysis with Pulsed Amperometric Detection
}

\author{
Jessica S. Stefano, Ana Paula de Lima, Rodrigo H. O. Montes, \\ Eduardo M. Richter and Rodrigo A. A. Muñoz*
}

Instituto de Química, Universidade Federal de Uberlândia, Av. João Naves de Ávila 2121, Bloco 1D, 38400-902 Uberlândia-MG, Brazil

\begin{abstract}
Um método eletroanalítico original e rápido para a determinação de naproxeno em formulações farmacêuticas usando análise por injeção em batelada (BIA) com detecção amperométrica pulsada é descrito. Eletrodo de carbono vítreo foi usado como eletrodo de trabalho e solução tampão fosfato $0,05 \mathrm{~mol} \mathrm{~L}^{-1}$ como eletrólito suporte. O método amperométrico envolveu a aplicação contínua de dois pulsos de potencial ao eletrodo de trabalho com intuito de detectar naproxeno pela sua oxidação eletroquímica (+1,5 V por $200 \mathrm{~ms})$ e de limpar a superfície do eletrodo de produtos de adsorção (+1,0 V por $100 \mathrm{~ms})$, evitando contaminação do eletrodo. O método proposto possui várias vantagens para análises de rotina, incluindo: baixo desvio padrão relativo $(3,0 \%, \mathrm{n}=10)$, elevada frequência analítica $\left(90 \mathrm{~h}^{-1}\right)$, exatidão satisfatória (baseado em determinações comparativas por espectrofluorimetria) e baixo limite de detecção $\left(0,3 \mu \mathrm{mol} \mathrm{L} \mathrm{L}^{-1}\right)$.
\end{abstract}

A novel and fast electroanalytical method for naproxen determination in pharmaceutical formulations using batch injection analysis (BIA) with pulsed amperometric detection is described. Bare glassy carbon electrode was used as working electrode and $0.05 \mathrm{~mol} \mathrm{~L}^{-1}$ phosphate buffer solution as supporting electrolyte. The amperometric method involved the continuous application of two sequential potential pulses to the working electrode in order to detect naproxen by its electrochemical oxidation $(+1.5 \mathrm{~V}$ for $200 \mathrm{~ms})$ and to clean the electrode surface from adsorption products $(+1.0 \mathrm{~V}$ for $100 \mathrm{~ms})$, avoiding electrode contamination. The proposed method has several advantages for routine analysis, including: a low relative standard deviation between injections $(3.0 \%, \mathrm{n}=10)$, high analytical frequency $\left(90 \mathrm{~h}^{-1}\right)$, satisfactory accuracy (based on comparative determinations by spectrofluorimetry) and low limit of detection $(0.3 \mu \mathrm{mol} \mathrm{L}-1)$.

Keywords: batch injection analysis, multiple-pulse amperometry, non-steroidal antiinflammatory drug

\section{Introduction}

Naproxen, 2-(6-methoxynaphthalen-2-yl) propanoic acid, is a non-steroidal anti-inflammatory drug (NSAID) derived from propionic acid and has been widely used as an over-the-counter analgesic, anti-inflammatory and antipyretic agent. It is also commonly used for the reduction of stiffness caused by conditions including kidney stones, rheumatoid arthritis and other inflammatory rheumatic diseases. ${ }^{1,2}$ NSAIDs have been associated with the increasing number of potentially cardiovascular events. However, a recent study classified naproxen as the least harmful NSAID in cardiovascular terms. ${ }^{3}$

*e-mail: raamunoz@iqufu.ufu.br
Different analytical methods have been proposed for the determination of naproxen in pharmaceutical formulations including spectrophotometry (UV region), ${ }^{4,5}$ spectrofluorimetry, ${ }^{6-8}$ capillary isotachophoresis ${ }^{9}$ and high-performance liquid-chromatography (HPLC) coupled with spectrophotometric, ${ }^{10}$ amperometric ${ }^{11}$ and mass spectrometric detectors. ${ }^{1}$ Nevertheless, these analytical methods require expensive equipment and reagents, are time-consuming and often necessitate laborious pre- and post-column derivatization procedures.

On the other hand, electroanalytical methods are simpler and provide faster response with comparable or better sensitivity than HPLC methods. Analytical methods employing differential pulse voltammetry (DPV) at a platinum electrode ${ }^{12}$ and at a boron-doped diamond (BDD) 
electrode ${ }^{13}$ were reported for the determination of naproxen in non-aqueous electrolyte (acetonitrile supported with $0.1 \mathrm{~mol} \mathrm{~L}^{-1} \mathrm{LiClO}_{4}$ ). BDD electrodes provide lower low background current and wide potential window ${ }^{14}$ and due to these characteristics, the determination of naproxen at the BDD electrode presented superior sensitivity. ${ }^{13}$ To our knowledge, there are no amperometric methods reported to the determination of naproxen and the electroanalytical methods developed for naproxen determination required non-aqueous electrolyte. ${ }^{12,13}$

The association of flow injection analysis (FIA) with electrochemical detectors for the development of analytical methods provides high-speed, sensitivity, selectivity, accuracy and precision. ${ }^{15,16}$ Batch injection analysis (BIA) presents similar characteristics and can be an interesting alternative to FIA in such a way that pumps and valves of the FIA system are not necessary and reduced volumes of carrier solutions are employed. ${ }^{17}$ The BIA system with amperometric detection requires an electronic micropipette that injects a sample plug directly onto the working electrode surface positioned in a wall-jet configuration. The working electrode as well as the reference and counter electrodes are immersed in a large-volume blank solution. ${ }^{18}$ The combination of BIA with pulsed amperometry has been recently proposed for simultaneous determinations in fuel, ${ }^{19}$ pharmaceutical and food samples..$^{20}$ Pulsed amperometry has also been applied to selective determinations of analytes at electrodes that undergo passivation due to adsorption of electrochemically generated oxidation products..$^{21,22}$

In the present study, it is reported an application of BIA with pulsed amperometric detection for fast determination of naproxen in pharmaceutical formulations. The application of two potential pulses provided naproxen detection by its electrochemical oxidation (at $+1.5 \mathrm{~V}$ for $200 \mathrm{~ms})$ without electrode contamination $(+1.0 \mathrm{~V}$ for $100 \mathrm{~ms}$ for electrode cleaning) using an aqueous electrolyte.

\section{Experimental}

\section{Reagents and samples}

Highly-pure deionized water $(\mathrm{R} \geq 18 \mathrm{M} \Omega \mathrm{cm})$ obtained from a Millipore Direct-Q3 water purification system (Bedford, MA, USA) was used to prepare all aqueous solutions. Analytical grade phosphoric acid $(85 \% \mathrm{~m} / \mathrm{v})$ from Impex (São Paulo, Brazil), sodium hydroxide from Dinamica (Diadema, Brazil) and naproxen from DEG (São Paulo, Brazil) were used without further purification. Working standard solutions were prepared immediately before use by appropriate dilution of stock solution.
Pharmaceutical formulations (tablets) were obtained from local drug stores. For each analysis, five tablets were powdered in a mortar and a weight correspondent to one tablet was dissolved in electrolyte.

\section{Electrochemical measurements}

All electrochemical measurements were performed using a $\mu$-Autolab Type III (Eco Chemie, Utrecht, Netherlands) controlled by GPES 4.9.007 software (General Purpose Electrochemical System).

A three-electrode configuration included a glassy carbon ( $\varnothing=1.5 \mathrm{~mm}, \mathrm{CH}$ instrument, Austin, TX, USA) as a working electrode, a platinum wire as a counter electrode and a miniaturized $\mathrm{Ag} / \mathrm{AgCl} / \mathrm{saturated} \mathrm{KCl}$ electrode as a reference electrode. ${ }^{23}$ Cleaning of the glassy carbon electrode was mechanically performed on a felt-polishing pad using an alumina powder suspension $(0.3 \mu \mathrm{m})$ and copiously rinsing with deionized water.

Amperometric measurements were performed using a lab-made electrochemical batch injection cell previously described, ${ }^{24}$ which consists of a $180 \mathrm{~mL}$ glass cylinder (internal diameter of $7 \mathrm{~cm}$ ) and two polyethylene covers firmly fitted at the top and bottom of the cylinder. At the top, the polyethylene cover contained 3 holes for the counter and reference electrodes and the micropipette tip (external diameter of $6.6 \mathrm{~mm}$ ). The distance between the electronic micropipette tip and the center of the working electrode (positioned oppositely to the micropipette tip) was adjusted around $2 \mathrm{~mm}$ distant in a wall-jet configuration.

Injections of standard solutions or samples were conducted using an Eppendorf electronic micropipette (Multipette ${ }^{\circledR}$ stream), which permitted injections from 10 to $1000 \mu \mathrm{L}$ (using a $1 \mathrm{~mL}$ Combitip ${ }^{\circledR}$ ) at a programmable dispensing rate (from 28 to $330 \mu \mathrm{L} \mathrm{s}^{-1}$ ).

Conventional or multiple-pulse amperometric technique was selected to perform amperometric measurements using a constant potential or two potential pulses. A $0.05 \mathrm{~mol} \mathrm{~L}^{-1}$ phosphate buffer solution ( $\mathrm{pH} 7.5)$ was used as supporting electrolyte.

All electrochemical measurements were performed at room temperature, in the presence of dissolved oxygen.

\section{Spectrofluorimetric analysis}

Spectrofluorimetric determinations of naproxen were performed using a Hitachi F4500 apparatus in accordance with the literature. ${ }^{6}$ The standard solutions and samples were prepared in $0.05 \mathrm{~mol} \mathrm{~L}^{-1}$ phosphate buffer solution (pH 7.5). The wavelengths of fluorescence excitation and emission were kept at 271 and $353 \mathrm{~nm}$, respectively. 


\section{Results and Discussion}

Previous works exploiting voltammetry to investigate the electrochemical oxidation of naproxen were performed in non-aqueous solutions. ${ }^{12,13}$ However, naproxen is also soluble in water under slightly alkaline conditions. Therefore, the first experiments using cyclic voltammetry were carried out in a $0.05 \mathrm{~mol} \mathrm{~L}^{-1}$ phosphate buffer solution (pH 7.5) and in a $0.05 \mathrm{~mol} \mathrm{~L}^{-1} \mathrm{NaOH}$ solution at a glassy carbon electrode. The voltammograms revealed an irreversible oxidation peak at $0.95 \mathrm{~V}$ in phosphate buffer (data not shown). Cyclic voltammetric experiments were also performed in buffered solutions at different $\mathrm{pH}$ values (from 7.5 to 13) and the peak potential and the current intensity for naproxen oxidation did not change in the different solutions, suggesting that the electrochemical oxidation of naproxen is not $\mathrm{pH}$-dependent. Bosca et al. ${ }^{25}$ reported the decarboxylation of naproxen involving singleelectron transfer from the pi-system or the carboxylate moiety depending on the medium of electrochemical oxidation. In aqueous solution, the main product $(76 \%)$ of the electrochemical oxidation of naproxen (obtained by electrolysis at controlled potential) was a ketone derivative (with elimination of the carboxylate group). ${ }^{25}$ The proposed mechanism of the electrochemical oxidation occurs via a radical formation, followed by decarboxylation and formation of a hydroperoxide derivative, resulting in the ketone derivative. ${ }^{25}$

Next, constant-potential amperometry applying $+1.3 \mathrm{~V}$ using the BIA system was investigated for the determination of naproxen. Figure 1 presents a series of six successive injections of $50 \mu \mathrm{mol} \mathrm{L}^{-1}$ naproxen.

A constant decrease in the oxidation current was verified for successive injections of $50 \mu \mathrm{mol} \mathrm{L} \mathrm{L}^{-1}$ naproxen,

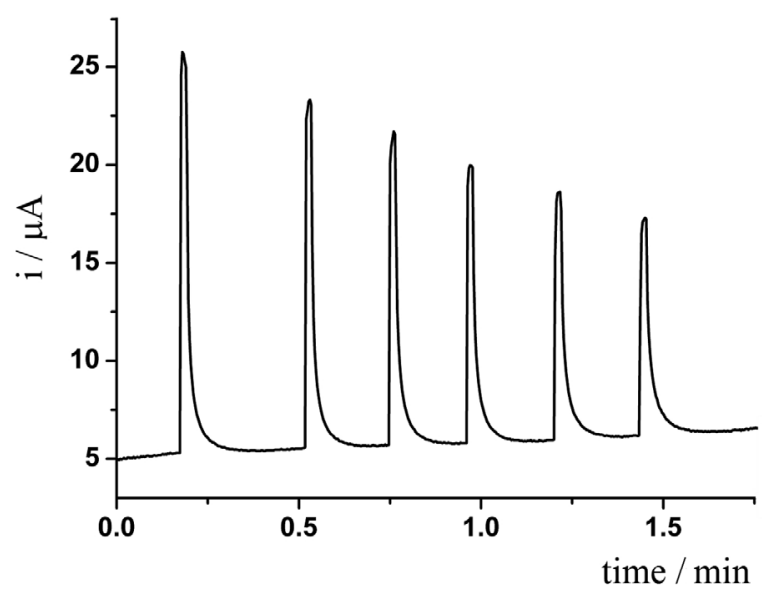

Figure 1. Amperometric recordings obtained from successive injections of $50 \mu \mathrm{mol} \mathrm{L}^{-1}$ naproxen. Working constant potential: $+1.3 \mathrm{~V}$; electrolyte: $0.05 \mathrm{~mol} \mathrm{~L}^{-1}$ phosphate buffer; injected volume: $200 \mu \mathrm{L}$; dispensing rate: $160 \mu \mathrm{L} \mathrm{s}^{-1}$. clearly indicating adsorption of naproxen or its oxidized products on the electrode surface blocking active sites. Cyclic voltammetric recordings have also demonstrated the blocking of the electrode surface (the oxidation signal of $1 \mathrm{mmol} \mathrm{L}^{-1}$ naproxen was completely depleted after the third consecutive cyclic scan). Previous electroanalytical methods for naproxen determination did report electrode adsorption processes resulted from the electrochemical oxidation of naproxen. ${ }^{12,13}$ However, those methods were performed in non-aqueous media whilst the present method employs an aqueous electrolyte, which can be an explanation for the different behavior. Previous works have demonstrated that pulsed amperometry is able to solve such a drawback by the application of an additional potential pulse for cleaning the electrode surface from adsorbed oxidation products. ${ }^{21,22}$ Thus, a sequence of two pulses was studied taking into consideration the detection of naproxen and the efficient electrode cleaning. This strategy resulted in highly repetitive current responses for naproxen injections. Figure 2 presents a set of 10 successive injections of $50 \mu \mathrm{mol} \mathrm{L} \mathrm{L}^{-1}$ naproxen applying $+1.5 \mathrm{~V}$ for $200 \mathrm{~ms}$ and $+1.0 \mathrm{~V}$ for $100 \mathrm{~ms}$. The highest current response for naproxen and the most efficient cleaning were verified under this sequence of potential pulse. The relative standard deviation $(\mathrm{RSD})$ was $3 \%(\mathrm{n}=10)$.

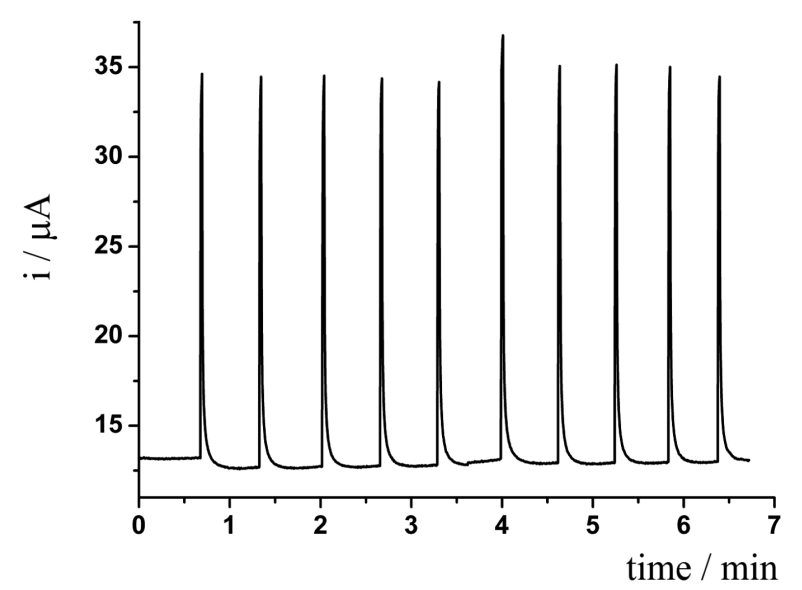

Figure 2. Repeatability data obtained from successive injections of $50 \mu \mathrm{mol} \mathrm{L}{ }^{-1}$ naproxen $(\mathrm{n}=10)$. Working potentials: $+1.5 \mathrm{~V}(200 \mathrm{~ms})$ and $+1.0 \mathrm{~V}$ (100 ms); electrolyte: $0.05 \mathrm{~mol} \mathrm{~L}^{-1}$ phosphate buffer; injected volume: $200 \mu \mathrm{L}$; dispensing rate: $160 \mu \mathrm{L} \mathrm{s}^{-1}$.

BIA parameters such as dispensing rate and injection volume controlled by the electronic micropipette were optimized. Figure 3 presents the variation of current response for naproxen in function of dispensing rate and injection volume.

The current peak increased, as long as the dispensing rate was increased (Figure $3 \mathrm{a}$ ). A dispensing rate of $160 \mu \mathrm{L} \mathrm{s}^{-1}$ was selected. Despite higher current 


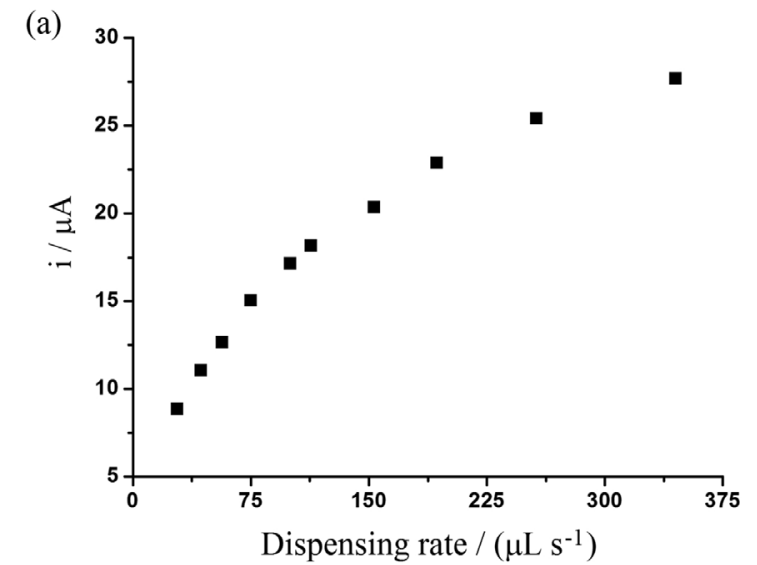

(b)

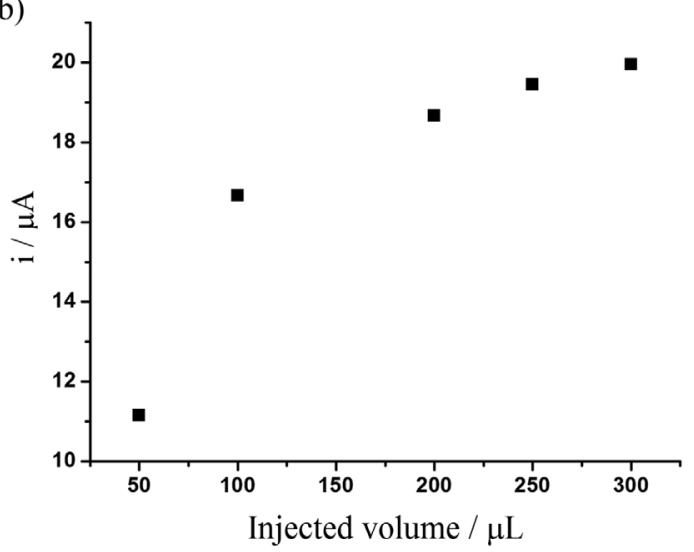

Figure 3. Effect of (a) dispensing rate and (b) injected volume on the current response for $50 \mu \mathrm{mol} \mathrm{L} \mathrm{L}^{-1}$ naproxen. Working potential: $+1.5 \mathrm{~V}$ $(200 \mathrm{~ms})$ and $+1.0 \mathrm{~V}(100 \mathrm{~ms})$; electrolyte: $0.05 \mathrm{~mol} \mathrm{~L}^{-1}$ phosphate buffer; injected volume: $200 \mu \mathrm{L}$ in (a); dispensing rate: $154 \mu \mathrm{L} \mathrm{s}^{-1}$ in (b).

responses were verified at higher dispensing rates, low repeatability (high standard deviation) was verified at higher dispensing rates than $160 \mu \mathrm{L} \mathrm{s}^{-1}$. The current peak increased significantly with increasing injection volume, from 50 to $100 \mu \mathrm{L}$, and continued to increase slightly from 100 to $300 \mu \mathrm{L}$ (Figure 3b). The injection volume of $200 \mu \mathrm{L}$ was selected for further experiments.

The linear dynamic range under optimized conditions was from 10 to $125 \mu \mathrm{mol} \mathrm{L}^{-1}$ naproxen. The current response did not increase linearly for naproxen concentrations higher than $125 \mu \mathrm{mol} \mathrm{L}^{-1}$. The limits of detection (LOD) and quantification (LOQ) under optimized conditions were estimated as 0.30 and $1.00 \mu \mathrm{mol} \mathrm{L}{ }^{-1}$, respectively $\left(\mathrm{LOD}=3 \mathrm{~s}_{\mathrm{B}} / \mathrm{S}\right.$ and LOQ $=10 \mathrm{~s}_{\mathrm{B}} / \mathrm{S}$, in which $\mathrm{s}_{\mathrm{B}}$ is the standard deviation of the intercept and $\mathrm{S}$ is the slope of the calibration curve). The obtained LOD values for naproxen determined by DPV at platinum ${ }^{12}$ and at BDD electrodes ${ }^{13}$ were 0.9 and $0.03 \mu \mathrm{mol} \mathrm{L}^{-1}$, respectively. However, both electroanalytical procedures employed non-aqueous electrolyte. ${ }^{12,13}$ Figure 4 presents amperometric responses for triplicate injections of solutions containing increasing concentrations of naproxen (a-e: $10-100 \mu \mathrm{mol} \mathrm{L}^{-1}$ ). The respective calibration curves (increasing and decreasing order) are also presented (inset). The analytical frequency estimated in this amperometric recording is higher than $90 \mathrm{~h}^{-1}$ (much superior than the DPV methods previously reported). ${ }^{12,13}$

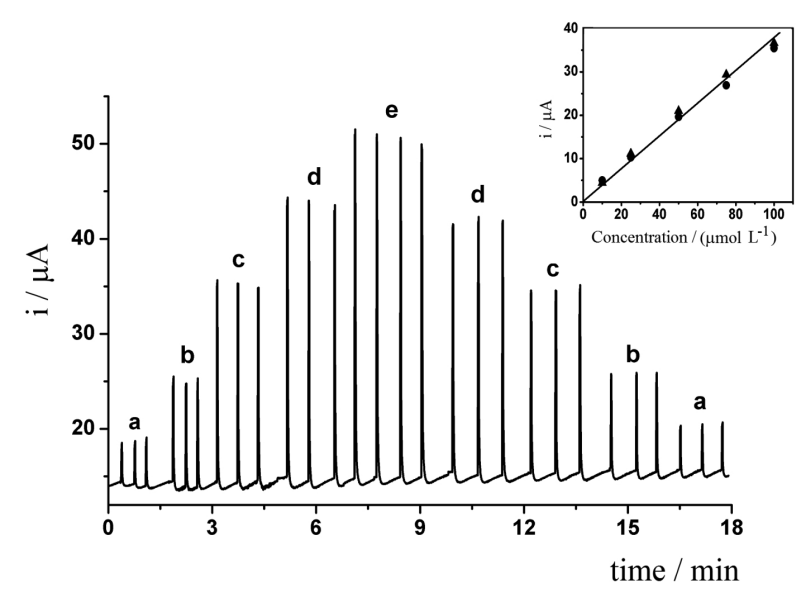

Figure 4. BIA amperometric responses for triplicate injections of (a) 10 , (b) 25, (c) 50, (d) 75 and (e) $100 \mu \mathrm{mol} \mathrm{L}^{-1}$ naproxen standard solutions. Inset: the corresponding calibration curves for increasing $(\boldsymbol{\Lambda})$ and decreasing $(\bullet)$ injection order. Working potential: $+1.5 \mathrm{~V}(200 \mathrm{~ms})$ and $+1.0 \mathrm{~V}$ (100 ms); electrolyte: $0.05 \mathrm{~mol} \mathrm{~L}^{-1}$ phosphate buffer; injected volume: $200 \mu \mathrm{L}$; dispensing rate: $160 \mu \mathrm{L} \mathrm{s}^{-1}$.

A linear behavior, with a good correlation coefficient ( $\mathrm{R}>0.99$ ), was observed from 10 to $100 \mu \mathrm{mol} \mathrm{L}^{-1}$ naproxen with similar slope values for both curves $(0.357$ and $\left.0.336 \mu \mathrm{A} \mathrm{L} \mu \mathrm{mol}^{-1}\right)$. Electrode fouling was not verified between injections of standard solutions, as evidenced by the fact that current responses were not diminished during amperometric measurements due to the application of a cleaning potential pulse $(+1.0 \mathrm{~V})$ using the pulsed amperometric detection technique.

The optimized BIA method with pulsed amperometric detection was applied for the determination of naproxen in pharmaceutical formulations. For comparison, the samples were also analyzed by spectrofluorimetry based on a previous work. ${ }^{6}$ Results are presented in Table 1 .

Table 1. Concentrations of naproxen obtained by the proposed BIA method and by spectrofluorimetry (mg per tablet) and the respective standard deviation values $(n=3)$.

\begin{tabular}{lccc}
\hline Sample & Label value / mg & BIA / mg & Spectrofluorimetry / mg \\
\hline 1 & 500 & $484 \pm 33$ & $507 \pm 16$ \\
2 & 550 & $557 \pm 3$ & $570 \pm 13$ \\
\hline
\end{tabular}

All results obtained by the proposed BIA method were in agreement with those obtained by spectrofluorimetry (Table 1). At the 95\% confidence level, the calculated $t$-values (paired student's $t$-test) were smaller than the critical value $(2.78, \mathrm{n}=3)$, indicating that there are no 
significant differences between the results. The presence of solid particles from sample matrix (excipients) in solution did not affect the amperometric measurement and then a filtration step was not necessary (advantage of electrochemical methods in comparison with optical ones).

\section{Conclusions}

It was demonstrated, for the first time, the application of BIA with amperometric detection for the determination of naproxen in pharmaceutical formulations. The proposed method is highly precise ( $\mathrm{RSD}=3 \%, \mathrm{n}=10$ ), accurate (confirmed by comparison with the spectrofluorimetric method), sensitive (LOD of $0.30 \mu \mathrm{mol} \mathrm{L} \mathrm{L}^{-1}$ ) and fast (90 injections $\mathrm{h}^{-1}$ ). Therefore, this method can be applied for routine analyses at a high analytical frequency.

\section{Acknowledgements}

The authors are grateful to $\mathrm{CNPq}$ (Conselho Nacional de Desenvolvimento Científico e Tecnológico, 478081/2010-3 and 305227/2010-6), FAPEMIG (Fundação de Amparo à Pesquisa do Estado de Minas Gerais, CEX-APQ-01856-10) and CAPES (Coordenação de Aperfeiçoamento de Pessoal de Nível Superior) for financial support. The authors also thank L. G. Silva for technical assistance in the spectrofluorimetric analyses.

\section{References}

1. Elsinghorst, P. W.; Kinzig, M.; Rodamer, M.; Holzgrabe, U.; Sorgel, F.; J. Chromatogr., B: Anal. Technol. Biomed. Life Sci. 2011, 879, 1686.

2. Sun, Y.; Zhang, Z.; Xi, Z.; Shi, Z.; Talanta 2009, 79, 676.

3. Trelle, S.; Reichenbach, S.; Wandel, S.; Hildebrand, P.; Tschannen, B.; Villiger, P. M.; Egger, M.; Jüni, P.; Rev. Port. Clin. Geral 2011, 27, 118, DOI: 10.1136/bmj.d2218.

4. Holzbecher, M.; Ellenbeerger, H. A.; Marsh, J. M.; Boudreau, S.; Clin. Biochem. 1979, 12, 66.

5. Panderi, I.; Parissipoulou, M.; Analyst 1994, 119, 697.
6. Damiani, P.; Bearzotti, M.; Cabezon, M. A.; J. Pharm. Biomed. Anal. 2002, 29, 229.

7. Ibanez, G. A.; Escandar, G. M.; J. Pharm. Biomed. Anal. 2005, $37,149$.

8. Junquera, E.; Aicart, E.; Int. J. Pharm. 1999, 176, 169.

9. Sadecka, J.; Cakrt, M.; Hercegova, A.; Polonsky, J.; Skacani, I.; J. Pharm. Biomed. Anal. 2001, 25, 881.

10. Wainer, I. W.; Doyle, T. D.; J. Chromatogr. 1984, 284, 117.

11. Kazemifard, A. G.; Moore, D. E.; J. Chromatogr., B: Anal. Technol. Biomed. Life Sci. 1990, 533, 125.

12. Adhoum, N.; Monser, L.; Toumi, M.; Boujlel, K.; Anal. Chim. Acta 2003, 495, 69.

13. Suyanarayanan, V.; Zhang, Y.; Yoshihara, S.; Shirakashi, T.; Electroanalysis 2005, 17, 925.

14. Tormin, T. F.; Gimenes, D. T.; Richter, E. M.; Munoz, R. A. A.; Talanta 2011, 85, 1274.

15. Felix, F. S.; Angnes, L.; J. Pharm. Sci. 2010, 99, 4784.

16. Gimenes, D. T.; Dos Santos, W. T. P.; Tormin, T. F.; Munoz, R. A. A.; Richter, E. M.; Electroanalysis 2010, 22, 74.

17. Quintino, M. S. M.; Angnes, L.; Electroanalysis 2004, 16, 513.

18. Wang, J.; Taha, Z.; Anal. Chem. 1991, 83, 1053.

19. Tormin, T. F.; Cunha, R. R.; Richter, E. M.; Munoz, R. A. A.; Talanta 2012, 99, 527.

20. Da Silva, R. A. B.; Gimenes, D. T.; Tormin, T. F.; Munoz, R. A.A.; Richter, E. M.; Anal. Methods 2011, 3, 2804.

21. Tormin, T. F.; Gimenes, D. T.; Silva, L. G.; Ruggiero, R.; Richter, E. M.; Ferreira, V. S.; Munoz, R. A. A.; Talanta 2010, $82,1599$.

22. Lacourse, W. R.; Johnson, D. C.; Rey, M. A.; Slingsby, R. W.; Anal. Chem. 1991, 63, 134.

23. Pedrotti, J. J.; Angnes, L.; Gutz, I. G. R.; Electroanalysis 1996, $8,673$.

24. Silva, R. A. B.; Montes, R. H. O.; Richter, E. M.; Munoz, R. A. A.; Food Chem. 2012, 133, 200.

25. Bosca, F.; Martinez-Manez, R.; Miranda, M.A.; Primo, J.; Soto, J.; Vano, L.; J. Pharmac. Sci. 1992, 81, 479.

Submitted: April 29, 2012

Published online: October 9, 2012 